\title{
DEBATES
}

\section{Fake news em imagens: um esforço de compreensão da estratégia comunicacional exitosa na eleição presidencial brasileira de 2018}

\author{
Fake news in pictures: understanding a successful communication \\ strategy in the Brazilian presidential election of 2018
}

\section{Irineu Francisco Barreto Junior Gustavo Venturi Junior}

\section{Resumo}

Este artigo propóe uma análise da estratégia comunicacional adotada na eleição presidencial de 2018, vencida pelo entấo deputado federal Jair Bolsonaro, e que teve como um de seus pilares a disseminaçấo de notícias falsas, impulsionadas por redes sociais e grupos de WhatsApp e cuja prática se convencionou chamar como fake news. O estudo realiza uma análise teórica e conceitual do fenômeno das fake news com o intuito de diferenciá-las de meras notícias falsas e da necessária concatenação entre as mensagens propagadas e elementos reais do contexto político no qual estão inseridos os eleitores aos quais procuram influenciar. Adotou-se na coleta dos dados a técnica de pesquisa netnografia, e o estudo concluiu que a eleição presidencial de 2018 foi uma tempestade perfeita para a efetividade da estratégia comunicacional fundada em distorçôes e fraudes, eivada de fatores que criaram o ecossistema político propício à disseminação das fake news.

\section{Palavras-chave}

Fake News; Eleiçóes; Política Brasileira; WhatsApp; Redes Sociais.

\section{Abstract}

This paper proposes an analysis of the communication strategy adopted in the 2018 presidential election, won by the then federal deputy Jair Bolsonaro, and which had as one of its pillars the spread of news driven by social networks and WhatsApp groups, whose practice has been conventionally called fake news. The study conducts a theoretical and conceptual analysis of the fake news phenomenon in order to differentiate them from mere false news, as well as an analysis of the necessary concatenation between the propagated messages and real political context elements in which the voters they seek to influence are inserted. The study adopted the data collection technique called netnography and concluded that the 2018 presidential election was a perfect storm for the communication strategy effectiveness based on distortions and fraud, and that it was riddled with factors that created the political ecosystem conducive to the fake news spread.

\section{Keywords}

Fake News; Elections; Brazilian Politics; WhatsApp; Social Networks. 


\section{Introdução}

Este artigo realiza uma análise da estratégia comunicacional adotada na eleição presidencial brasileira de 2018, vencida pelo então deputado federal Jair Bolsonaro, e analisa a hipótese de que essa tática teve como um de seus pilares a disseminação de notícias fraudulentas, intencionalmente deturpadas ou enviesadas e deliberadamente impulsionadas por redes sociais e grupos de WhatsApp. Tal prática convencionou-se denominar como fake news.

A pesquisa objetivou analisar a disseminação dessas mensagens por redes sociais e grupos de WhatsApp durante a campanha presidencial de 2018 e apontar possíveis efeitos dessa prática nos resultados do pleito. Para tal, foi necessário compreender o fenômeno das fake news e as inovaçóes, a partir delas advindas, no cenário das décadas recentes, nas quais o uso de ferramentas comunicacionais de Internet foi sendo disseminado como estratégia eleitoral. Com esse intuito, o estudo realiza uma análise teórica e conceitual do fenômeno das fake news, com o objetivo de diferenciá-las de meras notícias falsas e evidenciar as nuances que apontam a intencionalidade de sua propagação.

$\mathrm{O}$ artigo resgata a adoção de estratégias de impulsionamento pago de mensagens durante a campanha eleitoral de 2018, por WhatsApp e redes sociais, e problematiza a hipótese de que, para que essa prática fosse exitosa e surtisse efeitos eleitorais, seria necessário que houvesse uma concatenação entre esses conteúdos e elementos reais do contexto social, comportamental e cultural no qual estão inseridos os eleitores ou cidadãos aos quais procuram influenciar. Essa foi a problematização formulada na pesquisa, cujos resultados são ora apresentados.

Com efeito, para realizar uma aproximação entre a estratégia de disseminação em massa de mensagens e seus reflexos na campanha eleitoral, o artigo correlaciona dados das pesquisas eleitorais Datafolha e Ibope - intenção de voto e taxas de rejeição dos principais candidatos, divulgadas entre os dias 20 de agosto e seis de outubro de 2018, véspera do primeiro turno do sufrágio, com o intuito de estimar potenciais efeitos das fake news.

Adota-se na coleta dos dados a técnica de pesquisa denominada netnografia, que consiste no registro e análise de manifestaçóes sociais, culturais ou políticas na Internet, para posterior interpretação e atribuição de significados. Com base nesse enfoque, a pesquisa compilou, entre setembro e novembro de 2018 , em torno de 160 
imagens que circularam em grupos ${ }^{1}$ de WhatsApp e que podem ser associadas à estratégia de propagação das fake news.

A abordagem das imagens adotou enfoque qualitativo, uma vez que a pesquisa não almejou mensurar quantitativamente esse fenômeno e sim analisar o conteúdo simbólico das denominadas notícias falsas. Com esse intuito, o artigo disponibiliza online imagens elucidativas das fake news ${ }^{2}$, selecionadas a partir de critérios que permitiram enquadrá-las quanto à sua relevância, concatenação com aspectos mais gerais da política brasileira - o que lhes atribui, potencialmente, certa aura de credibilidade -, e estabelecer nexos entre seus teores e a campanha presidencial brasileira de 2018 .

\section{Disseminação da expressão fake news e sua necessária formulação conceitual}

As eleições presidenciais brasileiras de 2018 se anunciavam, de antemão, como potencialmente atípicas, submetidas a reflexos do novo estágio de polarização da sociedade brasileira, inaugurado nos protestos de junho de 2013, e que prosseguiu com a Operação Lava Jato, responsável por investigar e julgar casos de corrupção que afetaram as maiores agremiações partidárias do establishment brasileiro. Os prognósticos eleitorais previam que a agenda eleitoral seria influenciada pelo impeachment da ex-presidente Dilma Rousseff; prisão do ex-presidente Lula; greve dos caminhoneiros, que paralisou o país no ano eleitoral; e o assassinato da vereadora e ativista Marielle Franco - entre outros eventos que sedimentaram o final do ciclo histórico inaugurado com a Constituição Federal de 1988.

Nesse cenário, e nas décadas recentes, revestiu-se de alcance a adoção das redes sociais e aplicações comunicacionais de Internet como ferramentas de estratégia política, ocupando paulatinamente o espaço da mídia mainstream e da tradicional ocupação das ruas e praças públicas para campanhas eleitorais (BARRETO JUNIOR e VENTURI JUNIOR, 2017). Ferramentas de e-mail e redes sociais como Facebook e Twitter já haviam sido introduzidas na comunicação política de pleitos anteriores, e as eleições brasileiras de 2018 presenciaram a adoção de uma nova tecnologia: o

\footnotetext{
1 A pesquisa almejou extrapolar círculos específicos de apoiadores de campanha, cujos resultados seriam pouco efetivos em razão do engajamento pretérito dos seus membros e, para tal finalidade, compilou imagens enviadas em grupos de WhatsApp interpessoais apolíticos e aleatórios.

${ }^{2}$ Conforme as normas editoriais do periódico, as imagens foram abrigadas online, sob responsabilidade dos autores do artigo, e estão disponíveis em: <https:/www.portalsid.com/fake-news-em-imagens>.
} 
WhatsApp. Essa ferramenta possui uma série de atipicidades em relação às suas congêneres de Internet, que serão tratadas no artigo.

Em razão da vulgarização recente desse termo, que passou a ser adotado por políticos no intuito de negar denúncias relacionadas aos seus nomes, apresenta-se como necessária a reformulação conceitual da expressão. $\mathrm{Na}$ literatura, o fenômeno tem adquirido caráter polissêmico e tem sido relacionado aos seguintes termos: desinformação; negação da realidade factual; distorção; boatos; rumores; teorias da conspiração; intencionalidade; não espontaneidade; mentiras; fraudes; equívocos; poluidoras da qualidade do debate público.

Com o intuito de formular um conceito mais preciso do que são fake news, faz-se importante observar a analogia estabelecida por Wu et al. (apud RAIS, 2018, p. 63), entre esse termo e as expressões, em língua inglesa, misinformation e desinformation. Apesar de similares, possuem significados bem distintos. "Em inglês, misinformation é uma informação falsa ou imprecisa espalhada de forma não intencional, enquanto desinformation é intencionalmente falsa e deliberadamente propagada". Nessa perspectiva, as fake news devem ser consideradas como desinformação, ou seja, informação criada com o propósito deliberado de enganar ou enviesar os usuários, e é comumente espalhada e reforçada nas redes. Castro (2018) sintetiza o conceito de Allcott e Gentzkow (2018, p. 64), os quais:

[...] definem fake news como sendo aquelas notícias que são intencionalmente e verificavelmente falsas, que poderiam enganar os leitores, ou seja, desinformação. Essa definição enfatiza duas características centrais das fake news: autenticidade (é possível validá-las) e intencionalidade (possuem o intuito de enganar), o que levou a uma definição mais estrita: são notícias intencionalmente e verificavelmente falsas. Tal definição exclui erros jornalísticos não intencionais; rumores (informaçôes que não são verificavelmente falsas no momento da postagem); teorias de conspiração; sátiras; fofocas (afirmaçôes não validadas e não consentidas) e declaraçóes falsas.

O aspecto supramencionado, que aponta como atributo das fake news o fato de que é possível validá-las, fez com que a Internet se tornasse um campo propício à 


\section{8 | Irineu Francisco Barreto Junior e Gustavo Venturi Junior}

difusão de sites e portais hiperpartidarizados ${ }^{3}$, dos diferentes campos do espectro político, produtores de conteúdo meticulosamente customizado para propagaçáo em redes e ferramentas comunicacionais. Esses portais foram apontados como decisivos como produtores de conteúdo na eleição de Trump e hoje fazem parte do ecossistema político brasileiro, com enorme influência em sua cena.

Novos elementos conceituais importantes são encontrados na taxonomia sugerida pela jornalista Claide Wardle (apud RAIS, 2018, p. 108), que criou uma tipologia de sete tipos de notícias falsas - classificação que auxilia na compreensão da estratégia comunicacional:

1. Sátira ou paródia: sem intenção de causar mal, mas tem potencial de enganar;

2. Falsa conexão: quando manchetes, imagens ou legendas dão falsas dicas do que é realmente o conteúdo;

3. Conteúdo enganoso: uso enganoso de informação para usá-la contra um assunto ou uma pessoa;

4. Falso contexto: quando um conteúdo genuíno é compartilhado com um contexto falso;

5. Conteúdo impostor: quando fontes (pessoas, organizaçóes, entidades) têm seus nomes usados, mas com afirmaçóes que não são suas;

6. Conteúdo manipulado: informaçôes ou ideias verdadeiras são manipuladas para enganar o público;

7. Conteúdo fabricado: feito do zero, é $100 \%$ falso e construído com o intuito de desinformar o público e causar algum mal.

O primeiro item da classificação de Wardle, sátira ou paródia, não foi incluído na tipologia formulada por Allcott e Gentzkow, apresentada anteriormente, o que não representa entrave para a incorporação dessa taxonomia na delimitação conceitual do fenômeno. Os demais pontos dessa classificação representam conteúdo fartamente disseminado durante a eleição presidencial de 2018 e que continuou a alimentar a construção de narrativas políticas nas redes e grupos de WhatsApp.

Observa-se, então, a distinção necessária entre o conceito em construção e a mera noção de notícias falsas. Fake news são bastante sofisticadas, planejadas desde sua gênese, disseminadas de forma intencional com o intuito de atingir objetivos econômicos ou políticos bastante específicos. Gross (2018, p. 157) acrescenta a este

\footnotetext{
${ }^{3}$ A ação desses portais hiperpartidarizados perdura nos períodos pós-eleitorais como estratégia política e comercial. Mensagens polarizadas ou simplesmente distorcidas servem como caça cliques, e a outrora estratégia preponderantemente política agora serve também como atrativo de marketing.
} 
escopo o advento da nova era informacional denominada Sociedade da Informação, classificando o termo como "[...] um tipo novo de conteúdo produzido a partir de uma intencionalidade apenas viabilizada pelo modo de produção, disseminação e consumo de conteúdo online" (GROSS, 2018, p. 157, grifo nosso). A autora ainda amplia sua conceituação:

Trata-se do conteúdo mentiroso, ou seja, intencionalmente falso, fabricado com o objetivo de explorar as circunstâncias do universo online (anonimato, rapidez de disseminação da informação, fragmentação das fontes de informação e da atenção dos usuários da Internet e o apelo às emoçôes e ao sensacionalismo) para fins de obtenção de vantagens econômicas ou políticas. (GROSS, 2018, p. 157, grifo nosso).

Não é possível descartar a existência de pessoas que, mesmo de boa-fé ou de forma não-intencional, também acabam fazendo parte dos elos de disseminação das mensagens poluídas. Segundo Rais (2018, p. 108), “[...] há verdadeiras fábricas de fake news espalhadas pelo mundo cujo objetivo, por mais variado que seja, converge para a obtenção de alguma vantagem". Sobre pessoas que inadvertidamente passam a compor esse imensurável blockchain de disseminação e propagação de conteúdo, Rais (2018, p. 108) afirma:

É muito comum o uso das primeiras vítimas como uma espécie de elo para compor uma corrente difusora das fake news. Assim, aquelas pessoas que de boa-fé acreditaram estar em contato com uma verdadeira notícia, passam, ainda que sem perceber, a colaborar com a disseminaçáo e difusão dessas notícias falsas. Portanto, boa parte de toda essa proteção se escoa com o apoio das próprias vítimas.

Além desses inocentes úteis, há várias estratégias artificiais de disseminação de conteúdo pela Internet que advêm do avanço das tecnologias de comunicação e informação, viabilizadas pela disseminação em escala mundial da Internet. As estratégias artificiais mais comuns são os robôs, ciborgues, robôs políticos e ativistas em série, conforme classificação formulada pela rede de notícias BBC Brasil descrita a seguir. Essas táticas servem para inflar artificialmente a repercussão de postagens em redes sociais - pois quanto maior o número de interaçóes (curtidas, compartilhamentos e retuítes), mais ampla é a exposição orgânica das postagens - ou impulsionar mensagens via WhatsApp. 
a) Robôs: Algoritmos que automatizam o compartilhamento de notícias, também chamados de bots, e que são mais eficazes no Twitter.

b) Ciborgues: também conhecidos como trolls ou socketpuppets (fantoches), são híbridos entre robôs, movidos por algoritmos, e humanos que operam centenas de perfis falsos em redes sociais, agindo de forma e em horários diferentes que passem credibilidade para os demais usuários. Agem para impulsionar conteúdos previamente selecionados, curtindo, compartilhando e retuitando conforme a demanda.

c) Robôs políticos: identificados pela BBC Brasil, são uma outra categoria de robôs on-line que os define como "perfis de militantes que autorizam que suas contas sejam conectadas a páginas de candidatos ou de campanhas".

d) Perfis fake clássicos: perfis falsos criados para assegurar o anonimato ou a múltipla identidade de usuários das redes e ferramentas comunicacionais como o WhatsApp.

e) Ativistas em série: perfis reais altamente prolíficas, especialmente no Twitter, utilizados para fazer "subir as hashtags" conforme o funcionamento dessa plataforma, e são comumente acionados para propagar conteúdos com os quais os donos dos perfis possuem afinidade ideológica. Essa prática pode ser espontânea ou a soldo. (GRAGNANI, 2017).

A rápida velocidade e amplitude do espalhamento das fake news pode, segundo Shu et al. (apud CASTRO, 2018, p. 64), causar diversos impactos negativos nas pessoas e na sociedade, pois podem quebrar o equilíbrio de autenticidade do ecossistema de notícias, convencer intencionalmente os usuários de ferramentas comunicacionais sobre crenças falsas ou polarizadas e ainda transformar a forma como as pessoas respondem e interpretam as informações verdadeiras. Esse último aspecto merece atenção especial no Brasil.

A campanha vitoriosa nas eleiçôes presidenciais de 2018, que será analisada na próxima unidade, adotou um discurso francamente contrário ao establishment midiático e elegeu os meios tradicionais de comunicação do país - televisão, jornais e revistas - como componentes do rol de inimigos de sua plataforma. O Twitter e o WhatsApp são ainda constantemente acionados, mesmo após as eleiçóes, contra as mídias tradicionais, que são comumente acusadas como propagadoras de notícias falsas quando noticiam conteúdo desfavorável ao presidente ou ao seu grupo político. 
Algo que causa questionamentos sobre a real eficácia das fake news é que, não raro, seu teor parece exagerado, extravagante e caricato, fatores que levariam os receptores a imediatamente questionar sua autenticidade. É necessário observar que, apesar de procedente a assertiva de que parte do conteúdo parece inverossímil e pouco crível, essas mensagens normalmente despertam emoções ou crenças e, com a sociedade da informação e seus múltiplos efeitos na cultura e sociabilidade, há uma tendência de as pessoas serem menos cautelosas ao disseminarem notícias que coadunam com suas crenças ou visões de mundo. D’Ancona (2018) aponta que a maciça quantidade de informaçóes propagadas em tempo real pela Internet está gerando como consequência uma cacofonia, na qual a interação par a par tem substituído o imprimatur das mídias tradicionais. Assim, “[...] consumimos aquilo que já gostamos, evitamos o não familiar, o dínamo supremo da novidade também se tornou o curador do boato, do folclore, do preconceito" (D'ANCONA, 2018, p. 55).

E, conforme Rais e Hennemann (2018), o contrário também ocorre: "[...] as pessoas questionam tudo aquilo que vai de encontro às suas convicçôes, mesmo que seja pautado por argumentos e fatos verdadeiros. Uma grande parte está obstinadamente convencida do que determina para si ou para seu grupo endógeno". Os disparos de mensagens, portanto, partem de pontos de partida inflexíveis, premissas compartilhadas pelos diferentes grupos sociais, tornando-se a verdade, para Rais e Hennemann (2018) “[...] secundária em relação à afirmação narcísica de sua visão de mundo em rede”.

Esse fenômeno tem sido comumente associado à formação das bolhas, confinamentos criados em redes sociais e grupos de WhatsApp nos quais são circunscritos os usuários dessas tecnologias comunicacionais. A nomenclatura bolha denota a ideia de que há grande homogeneidade entre os membros desses confinamentos e, em razão disso, os usuários das tecnologias recebem apenas informaçóes similares àquelas com as quais já coadunam. Assim, passam a ser cercados de pessoas que pensam e se manifestam de forma muito parecida, seja no campo da política, ideologia, comportamento, religião, preferência futebolística ou estilo de vida. D’Ancona (2018, p. 55) aponta que a formação das bolhas não é um "defeito de projeto":

É aquilo que os algoritmos se destinam a fazer: conectar-nos com as coisas que gostamos, ou podemos vir a gostar. Trata-se de algo bastante responsivo ao gosto social e, até agora, bastante cego à veracidade. A web 
é o vetor definitivo da pós-verdade porque é indiferente à mentira, à honestidade e à diferença entre os dois.

Com o intuito de revestir as fake news de credibilidade, torna-se imprescindível que seus teores - mesmo que distorcidos ou deturpados - encontrem alguma aderência com o mundo real, ou seja, o contexto social, econômico, cultural, religioso ou moral que marcam os sucessivos ciclos históricos. Assim, mostra-se necessária a existência de uma infraestrutura ou superestrutura propícias à propagação da estratégia comunicacional em análise.

Sobre esse necessário aggiornamento entre fake news e o mundo real, Ross e Ward (apud CASTRO, 2018, p. 63) escrevem que “[...] como indivíduos temos um realismo ingênuo (do inglês naïve realism), por meio do qual acreditamos que a nossa percepção da realidade é o único ponto de vista correto, enquanto quem discorda de nós é visto como desinformado, irracional ou enviesado". E ainda, para os autores, os receptores de informaçôes são submetidos a vieses de confirmação (do inglês, confirmation bias) aos quais são mais suscetíveis, tendendo a preferir informações que corroboram sua própria visão do mundo e que mais se coadunam com suas crenças e percepçóes da realidade.

Rais $(2018$, p. 9) alerta que “[...] parece que tudo pode ser chamado de fake news, mas se algo pode ser tudo, provavelmente não poderá ser considerado algo em si mesmo". Ainda segundo o autor, o atual contexto se refere a "[...] notícias ou mensagens fraudulentas, propositadamente mentirosas, capazes de gerar dano efetivo ou potencial, em busca de vantagem" (RAIS, 2018, p. 107).

Este artigo adota o conceito de que fake news não são apenas notícias falsas. São componentes de estratégias comunicacionais bastante sofisticadas e que envolvem desde a produção de conteúdo deliberadamente fraudulento, falso, distorcido, enviesado ideologicamente, além de terem sua distribuição e impulsionamento pela Internet. Se notícias falsas sempre existiram, a grande novidade é a atual dimensão do fenômeno que advém do mundo digital e da hiperconectividade permitida com a Internet. São, portanto, frutos da cultura digital, cultura da rede. A próxima unidade do artigo esmiuçará a estratégia das fake news na eleição presidencial brasileira de 2018 e os principais episódios associados ao fenômeno ao longo desse ano e ponderará sobre seus possíveis efeitos no desfecho do pleito. 


\section{Fake news como estratégia comunicacional na eleição presidencial de 2018: o contexto brasileiro e como oportunizou a eficácia das fake news}

No campo da política brasileira, com seu ápice na eleição de 2018, a agenda setting eleitoral passou por um deslocamento de eixo. Outrora prioritárias, a consolidação da estabilidade econômica e a formulação de um conjunto de políticas públicas passaram a ser preteridas em nome do combate à corrupçáo. No caso das eleiçôes presidenciais, a campanha vitoriosa se aproveitou da débâcle econômica atravessada pelo país e da associação entre corrupção e partidos políticos fiadores do pacto pós-constituição de 1988, especialmente o Partido dos Trabalhadores - PT, e pautou seu discurso num ambiente hostil em relação às plataformas eleitorais mais progressistas, tais como a defesa das pautas de grupos minoritários, defesa dos direitos humanos.

Além da revelação dos casos de corrupção, merece destaque outro aspecto explorado pela campanha presidencial de Jair Bolsonaro: uma insatisfação difundida entre segmentos médios e conservadores da sociedade brasileira, provocada pelo estremecimento dos padróes morais hegemônicos, paulatinamente erigida ao longo das décadas pós-redemocratização, e marcada pela ampliação do protagonismo dos movimentos feministas, negros, indígenas, de trabalhadores sem-terra, sem-teto e pelo novo patamar de direitos civis alcançado pela comunidade LGBT. Esse contexto de estremecimento de padrões morais hegemônicos esteve tradicionalmente associado ao ideário de esquerda no Brasil, e as fake news surfaram na onda de reação conservadora, uma vez que as denúncias de corrupção difundiram a percepção de associação entre políticos tradicionalmente defensores das agendas ditas progressistas e os vultosos casos de corrupção revelados pela Lava Jato.

As redes sociais e o WhatsApp foram inundados por esses vieses em 2018. À crise econômica, amplificada por uma grande greve de caminhoneiros, foi somada a reação conservadora aos movimentos identitários; a percepção de aumento na criminalidade, elevação das taxas de desemprego; uma incipiente resposta na mobilidade socioeconômica esperada como efeito dos avanços na escolaridade média da população; falência do germinal modelo de políticas sociais e a relação episódica da maioria dos eleitores com a política - fatores estes que criaram a cultura propícia para disseminação das fake news, aqui denominada como tempestade perfeita. As imagens apresentadas ao término deste artigo e coletadas ao longo da campanha eleitoral refletem e conectam-se com essa tempestade perfeita. E, na eleição de 2018, os grupos 
de WhatsApp e Twitter revelaram-se como os meios de comunicação mais eficazes para disseminação das denominadas fake news, conforme será analisado em unidade específica deste paper.

Assinalam Ross e Ward (apud CASTRO, 2018, p. 63) que “[...] como seres sociais, temos uma tendência a aceitar conceitos e ideias compartilhadas pelas nossas redes, o que ajuda a definir nossa identidade e autoestima, nos mantendo em ambientes socialmente seguros". A partir dessas premissas, Castro (2018) aponta que redes de interação na Internet impõem uma exposição seletiva de conteúdo, o que:

[...] normalmente ocorre dentro desses grupos com pessoas que compartilham crenças e pensamentos, é o principal promotor de difusão de conteúdo, formando a geração de clusters homogêneos, conhecidos como câmaras de eco (do inglês, echo chambers) ou bolhas de filtros (filter bubbles), que isolam de perspectivas contrárias ou alternativas. (CASTRO, 2018, p. 63).

Ainda conforme Castro (2018, p. 63), “[...] esse efeito de câmara de eco facilita o consumo e a crença nas fake news devido à credibilidade social e a frequência de exposição a essas notícias". A eleição de 2018 foi uma tempestade perfeita para a efetividade de uma estratégia comunicacional fundada em distorções e fraudes.

\section{O case das eleições presidenciais de 2018}

A propagação mais comum de fake news na eleição presidencial de 2018 ocorreu via WhatsApp e Twitter, canais que se intercomunicaram e cujo alcance das mensagens decorreu, em grande parte, de propagação influenciada ou paga. O artigo apresentará, nesta unidade, pesquisas e matérias jornalísticas que demonstram ter havido, na eleição de 2018, distribuição de conteúdo eleitoral a cargo de ativistas em série (perfis com elevado número de seguidores e que atuam para "erguer" hashtags), bots (programas informáticos que imitam usuários reais, também conhecidos como robôs), ou disparo de mensagens em massa custeado por apoiadores da campanha vitoriosa.

Essa sensação era bastante difusa até que uma série de reportagens do jornal Folha de S. Paulo, inaugurada em 18 de outubro de 2018, denunciou que empresas dirigidas por apoiadores do então candidato Jair Bolsonaro haviam adquirido pacotes em massa de disparo de mensagens por WhatsApp contra o PT, partido do expresidente Lula, impedido judicialmente de disputar a eleição e preso na carceragem 
da Polícia Federal de Curitiba, e do candidato por ele indicado como sucessor, Fernando Haddad, que ocupava o segundo lugar nas pesquisas eleitorais. Conforme a referida reportagem (MELLO, 2018), as empresas apoiadoras de Bolsonaro adquiriram serviços denominados como "disparo em massa" que, conforme apuração da matéria, chegariam a custar R $\$ 12$ milhôes, e tais empresas teriam usado bases cadastrais do próprio candidato e bases vendidas por agências de estratégia digital para direcionar o encaminhamento via ferramenta WhatsApp. As agências oferecem segmentação dos destinatários por região geográfica e renda. Segundo a reportagem:

Entre as agências prestando esse tipo de serviços estão a Quickmobile, a Yacows, Croc Services e SMS Market. Os preços variam de R \$ 0,08 a R \$ 0,12 por disparo de mensagem para a base própria do candidato e de $\mathrm{R} \$$ 0,30 a $\mathrm{R} \$ 0,40$ quando a base é fornecida pela agência. As bases de usuários muitas vezes são fornecidas ilegalmente por empresas de cobrança ou por funcionários de empresas telefônicas. Empresas investigadas pela reportagem afirmaram não poder aceitar pedidos antes do dia 28 de outubro, data da eleição, afirmando ter serviços enormes de disparos de WhatsApp na semana anterior ao segundo turno comprados por empresas privadas. (MELLO, 2018).

O disparo das mensagens contra a candidatura de Fernando Haddad revestiuse, ainda, de aplicaçóes tecnológicas capazes de aumentar a eficácia da estratégia, tal qual o mascaramento do remetente por meio de números de telefone gerados automaticamente por sites abrigados fora do Brasil e que, segundo a reportagem, foram utilizados por funcionários das agências contratadas para administrar de forma dissimulada grupos de WhatsApp, participar de outros como membros e, com isso, escapar dos filtros de spam e das limitações impostas pelo WhatsApp ${ }^{4}$. Os administradores teriam usado algoritmos para segmentar os membros dos grupos entre detratores, apoiadores e neutros e, assim, customizar o conteúdo das mensagens com o intuito de otimizar seus efeitos sobre os destinatários.

A campanha de Bolsonaro e os empresários negaram a prática. O candidato Bolsonaro usou sua conta no Twitter para atacar a reportagem e os seus adversários, alegando que o incentivo que recebe de seus apoiadores é voluntário, que a campanha

\footnotetext{
${ }^{4}$ Naquele momento a ferramenta determinava o máximo de 256 participantes por grupo e repasse automático de uma mesma mensagem para até 20 grupos, posteriormente limitado a cinco, como estratégia para mitigar as Fake News no aplicativo.
} 
não pode responder pela ação de seus simpatizantes. No seu tuite, na Figura 1, o então candidato afirma:

Figura 1 - Tuite do então candidato Jair Bolsonaro

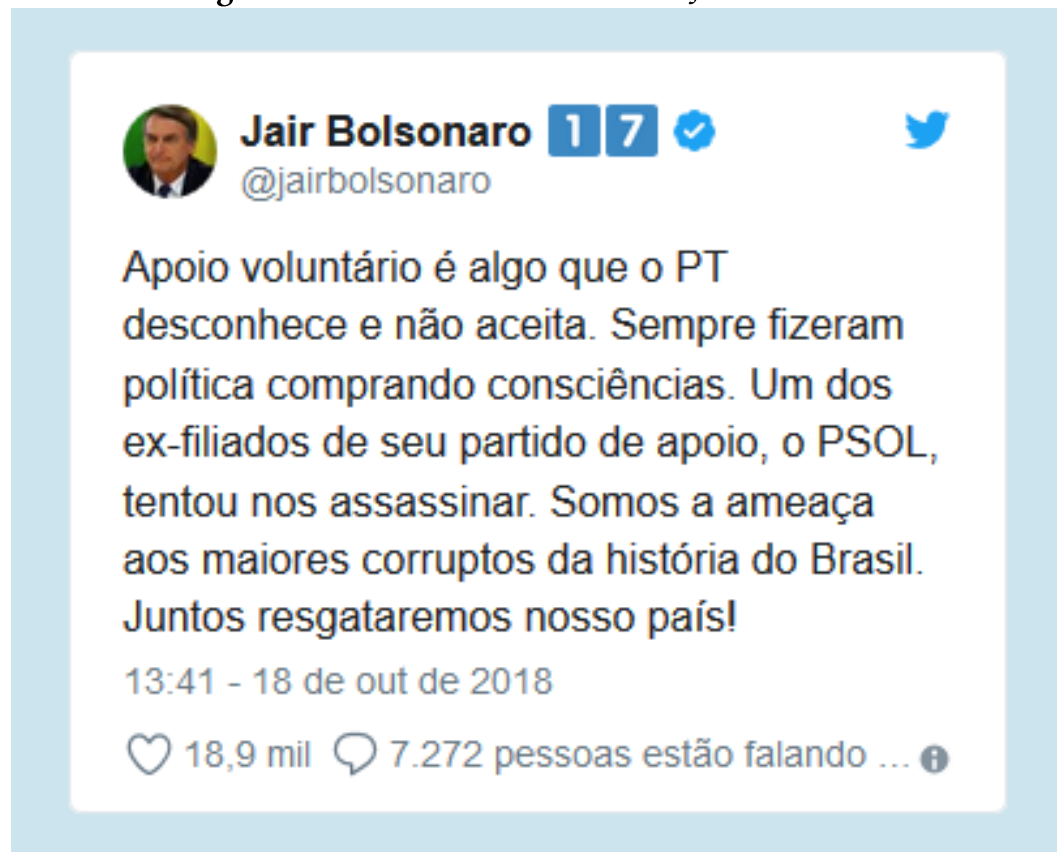

Fonte: Imagem do Twitter publicada na Folha de S. Paulo em 18 de outubro de 2018 (PASQUINI, 2018).

O tuite se refere ao atentado a faca sofrido pelo candidato na cidade de Juiz de Fora, em Minas Gerais, durante ato de campanha realizado no dia 6 de setembro de 2018 (JAIR BOLSONARO..., 2018). Após o atentado, o candidato passou por longo período de internações e cirurgias que o retirou dos principais atos de campanha e o levou a não conceder entrevistas e recusar-se a participar dos debates com os demais candidatos. É consensual nas esferas de análise política que o atentado protegeu o então candidato da exposição pública, o que lhe foi favorável tendo em vista sua posição nas pesquisas eleitorais, e que o retiro serviu para blindá-lo contra enfrentamentos que poderiam ser prejudiciais à sua performance eleitoral.

O candidato do PSL à presidência, Jair Bolsonaro, levou uma facada durante um ato de campanha em Juiz de Fora (MG), na tarde desta quinta-feira (6 de setembro de 2018). Ele era carregado nos ombros por 
apoiadores quando um homem se aproximou e o feriu na barriga. $\mathrm{O}$ agressor foi preso (veja no vídeo acima).

Bolsonaro foi socorrido e levado à Santa Casa de Misericórdia da cidade. O hospital informou que ele deu entrada na emergência, por volta de $15 \mathrm{~h} 40$, com "uma lesão por material perfuro cortante na região do abdômen". Segundo os médicos, Bolsonaro chegou com a pressão baixa por causa da perda de sangue. (JAIR BOLSONARO..., 2018).

A denúncia inaugural veiculada no jornal Folha de S. Paulo (MELLO e RODRIGUES, 2018) propiciou uma série de outras reportagens sobre as estratégias comunicacionais da campanha que viria a ser exitosa no pleito presidencial. Em nova matéria assinada por Patrícia Campos Mello e Artur Rodrigues, em 2 de dezembro de 2018, o jornal obteve acesso a uma ação em trâmite na Justiça do Trabalho de São Paulo, movida por um ex-funcionário da empresa Yacows, agência apontada como uma das contratadas por empresários apoiadores de Bolsonaro para disparo em massa de mensagens em prol da candidatura Bolsonaro. Segundo documentos anexados na ação trabalhista movida contra a Yacows, "[...] uma rede de empresas recorreu ao uso fraudulento de nomes e CPFs de idosos para registrar chips de celulares e garantir o disparo de lotes de mensagens em benefício de políticos" (MELLO e RODRIGUES, 2018).

Após a publicação da reportagem, o WhatsApp bloqueou as contas ligadas às quatro agências de mídia citadas pela Folha por fazerem disparos em massa: Quickmobile, Croc Services, SMS Market e Yacows. Nascimento descreve a atuação de três agências coligadas: Yacows, Deep Marketing e Kiplix, que funcionam no mesmo endereço em Santana (zona norte de São Paulo) e pertencem aos irmãos Lindolfo Alves Neto e Flávia Alves.

Segundo seu relato, as empresas cadastraram celulares com nomes, CPFs e datas de nascimento de pessoas que ignoravam o uso de seus dados. Ele enviou à reportagem uma relação de 10 mil nomes de pessoas nascidas de 1932 a 1953 (de 65 a 86 anos) que, afirma, era distribuída pela Yacows aos operadores de disparos de mensagens. Nascimento afirma que os dados utilizados sem autorização eram parte importante do esquema. (MELLO e RODRIGUES, 2018).

Ainda segundo Mello e Rodrigues (2018), a legislação que rege a telefonia brasileira exige o cadastro de CPFs existentes para liberar o uso de um chip. Em razão disso, a adoção do uso de números de documentos reais foi implementada para 
viabilizar a estratégia. Soma-se a isso o fator de que o WhatsApp “[...] trava números que enviam grande volume de mensagens para barrar spam, [assim,] as agências precisavam de chips suficientes para substituir os que fossem bloqueados e manter a operação" (MELLO e RODRIGUES, 2018). A reportagem ouviu, de Nascimento, que a linha de produção de mensagens funcionou ininterruptamente na campanha, e o entrevistado apresentou à reportagem fotos de computadores ligados a celulares e "chipeiras", além de caixas com chips de celulares5. Uma vez ativados, os chips eram usados em plataformas de disparo em massa de mensagens no WhatsApp, "[...] cerca de $99 \%$ para campanhas políticas e 1\% para a marca Jequiti (marca de cosméticos)”, segundo o relato (MELLO e RODRIGUES, 2018).

Figura 2 - Chips usados em empresa para enviar mensagens de WhatsApp em massa

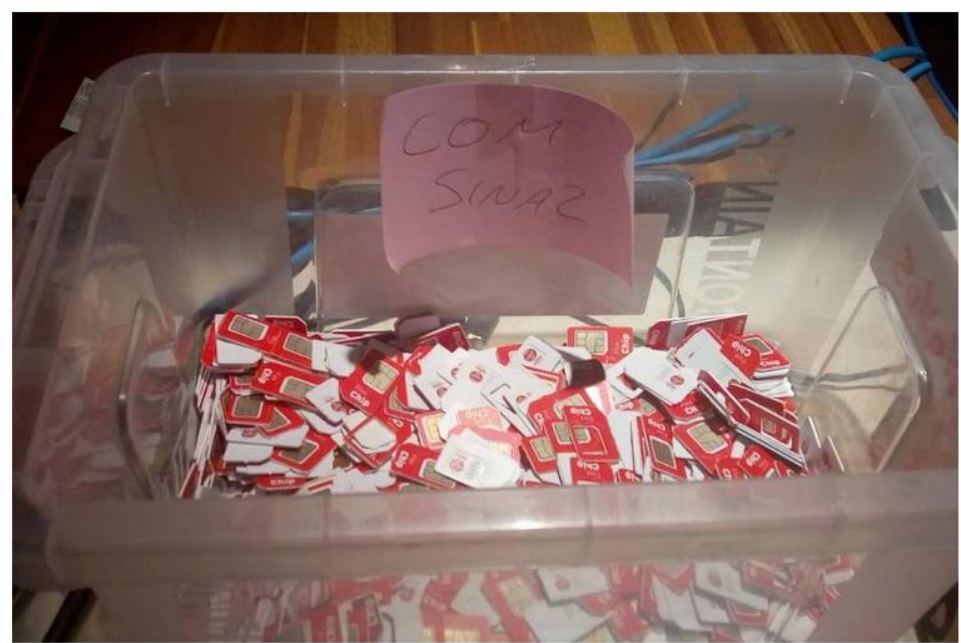

Chips usados em empresa para enviar mensagens de WhatsApp em massa - Reproduçăo

Fonte: Melo e Rodrigues (2018).

\footnotetext{
5 “Como 'Outro Lado’ na reportagem, A empresa Yacows, reafirma que não foi contratada em nenhum momento pela equipe da campanha do candidato Jair Bolsonaro para distribuir conteúdo eleitoral e pode dizer o mesmo das demais empresas que possuem sócios em comum, citadas pelas reportagens da Folha', diz, aludindo à Deep Marketing e à Kiplix. O TSE afirmou que a Yacows integra o polo passivo de uma ação cautelar e é investigada em outro processo. Mas 'o TSE não se pronuncia a respeito de casos sub judice’, diz nota” (MELLO e RODRIGUES, 2018).
} 
Figura 3 - Celulares usados em empresa para enviar mensagens de WhatsApp em massa

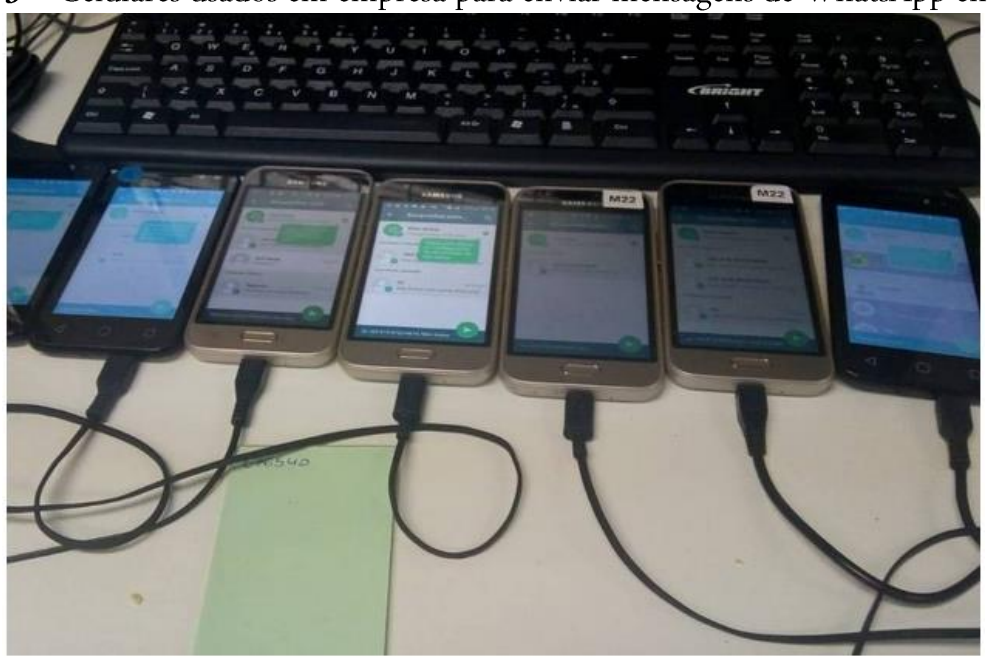

Fonte: Melo e Rodrigues (2018).

A movimentação atípica em grupos de WhatsApp pró-Bolsonaro foi verificada, no mesmo contexto anteriormente apontado, pelo Instituto de Tecnologia e Sociedade do Rio de Janeiro - ITS (MACHADO e KONOPACKI, 2019), centro de pesquisas que monitorou durante a última semana das eleições 110 grupos políticos abertos de WhatsApp e analisou seu grau de coordenação e interdependência. $\mathrm{O}$ estudo aponta para ação automatizada e envio coordenado de conteúdo pró-Bolsonaro para múltiplos grupos, com elevado grau de interconexão e número elevado de administradores e membros comuns, muitos com atividade dezenas de vezes acima da média de usuários comuns. $\mathrm{O}$ principal achado do estudo foi a potencial automação de envio de mensagens, demonstrada na hiperatividade de usuários com intervalo médio de disparo de mensagens entre 1 e 20 segundos, em parte significativa com perfis sem nome próprio ou foto pessoal - indícios da ação de robôs ou ciborgues, uma vez que os teores das mensagens não eram compostos por mensagens de opinião própria, mas majoritariamente a retransmissão de fotos ou vídeos.

O portal El País realizou um monitoramento de três grupos públicos de WhatsApp no mês de setembro de 2018, período que antecedeu as eleiçóes. Somados, esses grupos realizavam mais de mil publicaçóes por dia. A experiência revelou a "[...] difusão de mentiras camufladas como notícias, vídeos que tentam desmentir publicaçóes negativas da imprensa, desconfiança das pesquisas e falsos 
apoios de celebridades à candidatura Jair Bolsonaro" (BENITES, 2018). A matérias também relatou que "[...] há pelo menos cem grupos públicos específicos do aplicativo que apoiam o capitão reformado do Exército: 37 deles são monitorados pelo projeto Eleições Sem Fake, vinculado à Universidade Federal de Minas Gerais (UFMG)” (BENITES, 2018). Segundo Fabrício Benevenuto, professor do departamento de Ciência da Computação da UFMG e criador do projeto Eleiçóes sem Fake ${ }^{6}$ :

'Bolsonaro monopoliza os debates na maior parte dos grupos públicos. Monitoramos 272 grupos que debatem política, 37 deles só de Bolsonaro. Somos um sistema enviesado porque há mais grupos de apoiadores dele do que de outros candidatos'. De maneira geral, todos os grupos acompanhados servem para produzir respostas às notícias publicadas pela imprensa. Por exemplo, depois que, com base em documentos do Ministério das Relaçôes Exteriores, a Folha de S. Paulo noticiou que uma das ex-mulheres de Bolsonaro relatou ter sido ameaçada por ele em 2011, todos os grupos divulgaram um vídeo em que a Ana Cristina Valle "desmente" a informação. Ela é candidata a deputada federal pelo Rio de Janeiro e, com autorização de seu exmarido, passou a usar o mesmo sobrenome dele. (BENITES, 2018).

Para Benevenuto (apud BENITES, 2018), em outra frente, os grupos distribuem fake news, e alguns dos boatos mais disseminados foram os de que as urnas eletrônicas no Brasil já foram fraudadas; que Manuela D’Ávila (PCdoB), candidata a vice-presidente na chapa do petista Fernando Haddad (PT), teria recebido diversas ligaçôes de Adélio Bispo de Oliveira, responsável pelo atentado em que esfaqueou o então candidato Bolsonaro, no mesmo dia do atentado; e questionamentos que tentam imputar a culpa do ataque à facção criminosa Primeiro Comando da Capital (PCC) ou em adversários do político (BENITES, 2018).

Essas antecipaçōes de "notícias" também criam diversas teorias da conspiração. A jornalista Joice Hasselmann, que é candidata a deputada federal pelo PSL de São Paulo, divulgou um vídeo no qual diz que uma fonte confiável lhe disse que um órgão de imprensa teria recebido 600 milhóes de reais para, nesta reta final de campanha, detonar a candidatura de Bolsonaro. Mesmo que ela não tenha apresentado

\footnotetext{
${ }^{6}$ Disponível em: <http://www.eleicoes-sem-fake.dcc.ufmg.br/>.
} 
nenhuma prova, a notícia se propaga como fogo em mato seco. (BENITES, 2018).

Esse conjunto de notícias imputadas à campanha ou apoiadores de Bolsonaro estabelece nexos estreitos com a retórica do entâo candidato, eivada pelo discurso de que seu nome representava uma guerra santa contra o comunismo e inimigos externos, especialmente os riscos de que o Brasil poderia transformar-se numa nova Cuba ou nova Venezuela e, ainda, que o capitão reformado enfrentava adversários poderosos, tais como o establishment político e a mídia tradicional.

Nesse diapasão, a reportagem do El País e o monitoramento do programa Eleiçóes sem Fake identificaram que "[...] além da mobilização dos voluntários, a própria campanha de Bolsonaro distribuiu ela mesma informaçóes falsas, como a de que códigos das urnas eletrônicas foram passados à Venezuela ou mentiras a respeito da mobilização de mulheres" (BENITES, 2018). Refere-se, este último, ao maior ato de oposição à candidatura Bolsonaro, que ficou conhecido como \#elenão, uma série de manifestações lideradas por movimentos feministas, disseminados por propagação espontânea nas redes sociais, nas quais o repúdio ao candidato Bolsonaro foi a tônica, frente ao seu passado de manifestações consideradas misóginas e ofensivas contra mulheres e LGBTs, além das tradicionais diatribes em favor da tortura e do regime militar.

Sendo a mídia um dos seus alvos prioritários, os grupos pró-Bolsonaro não economizaram críticas sobre pesquisas eleitorais. Nesses grupos houve, ainda, falsas declaraçóes de apoio à Bolsonaro, como do apresentador e empresário Silvio Santos, o treinador e ex-goleiro Rogério Ceni e a cantora Sandy, todos desmentidos.

Os militantes creem que Bolsonaro será eleito no primeiro turno. Quando leem algo de que ele estancou nas pesquisas Ibope ou Datafolha abaixo dos $30 \%$ e que Fernando Haddad vem se aproximando dele, rapidamente dizem que os dados foram fraudados. Criticam a rede Globo, que costuma contratar alguns desses institutos, ou os jornais que a divulgaram, principalmente Folha de S. Paulo e O Estado de S. Paulo. A mensagem falsa de Silvio dizia o seguinte: "Desde quando fundei meu próprio canal [o SBT], sempre tive como princípio a união da família brasileira. Hoje, vejo somente uma pessoa disposta a praticar o mesmo princípio na política: o sr. Jair Bolsonaro. Por isso, ele tem não só o meu apoio, mas o meu voto e os votos de todos de minha família! ”. Em nota, o apresentador afirmou que náo declarou apoio a ninguém e que náo revela em quem votará. (BENITES, 2018). 
O Jornal gaúcho Zero Hora (ELY, 2018) identificou elementos importantes na estratégia de Bolsonaro, especialmente o papel dos filhos na campanha, que posteriormente refletiria no próprio governo, e a atuação de voluntários na rede de simpatizantes, sem a qual o uso do WhatsApp não teria sido bem-sucedido e a capilaridade atingida não seria factível. A matéria recorda que o então candidato possuía histórico de militante digital bem antes de entrar na corrida ao Palácio do Planalto e que contou, na campanha, com uma rede virtual tâo poderosa quanto barata. "Liderada pelos seus filhos, pensada por uma empresa especializada e disseminada pelos apoiadores, a estratégia alimenta a Internet com informações sobre a campanha e, claro, muito antipetismo" (ELY, 2018). A campanha foi marcada pelo baixo controle propiciado pelo uso do WhatsApp, e as redes receberam "[...] de dados fidedignos e críticas à imprensa até dúvidas infundadas sobre as urnas eletrônicas e mentiras camufladas de notícias" (ELY, 2018).

Vereador do Rio, o filho Carlos Bolsonaro (PSC) sempre foi o principal responsável pelos vídeos de edição simples e linguagem coloquial do pai. Durante a campanha, ganhou reforço: uma empresa de inteligência digital com sede em seis cidades do país que distribui conteúdo para cerca de 1,5 mil grupos de WhatsApp. A partir do primeiro envio, os materiais são compartilhados de maneira espontânea entre os apoiadores, estimulados a compartilhá-los. (ELY, 2018).

Para o professor da Universidade de São Paulo (USP) Márcio Ribeiro (ELY, 2018), um dos responsáveis pelo projeto "Monitor do debate político no meio digital", o sucesso está relacionado ao voluntarismo de simpatizantes do deputado federal espalhados pelo país. As regras do WhatsApp sinalizam o componente orgânico da campanha online - por limitar em 256 o número de participantes por "fórum", o sucesso de uso do aplicativo depende do engajamento de seus usuários para que as mensagens circulem.

De início, a estratégia "oficial" do time digital consistiu na criação de grupos de WhatsApp por Estado. Dali passaram a distribuir conteúdos diários aos apoiadores, vorazes compartilhadores de imagens, vídeos e memes de Bolsonaro. Ao que tudo indica, o limite de integrantes imposto pela ferramenta fez multiplicarem-se os grupos de WhatsApp.

Segundo estudo do pesquisador Maurício Moura, da Universidade George Washington, nos Estados Unidos, o conteúdo pró-Bolsonaro 
espraiou-se para 40 mil grupos de WhatsApp nos dias mais movimentados da campanha, sobretudo, nas duas semanas pré-votação. Em um dia "normal", chegou a 15 mil. (ELY, 2018).

Uma característica importante dos grupos é que muitos são públicos e, para participar, basta acessar um link, facilmente localizável em ferramentas de busca na Internet, o que assegurou a exponencial adesão de usuários de Internet, mesmo que sem engajamento político tradicional. Assim, a adesão que ocorreu de forma espontânea no ambiente político conflagrado das eleições de 2018. Márcio Ribeiro, pesquisador da USP, afirmou que a capacidade de encaminhar mensagens e criar grupos relativamente grandes colocou o WhatsApp em um lugar ambíguo: um espaço de comunicação privada onde é muito fácil e barato transmitir desinformação (ELY, 2018).

Um levantamento realizado pelo jornal O Estado de São Paulo (TOLEDO, 2018a) em parceria com a organização internacional de campanhas e mobilização social Avaaz, revelou que a estratégia comunicacional da campanha não foi exclusivamente realizada por WhatsApp e que houve articulação com redes sociais, e a produção de conteúdo foi, ao menos parcialmente, custeada por empresários. A investigação revela que um mínimo de 28 páginas e seis sites - que pertencem a um mesmo grupo chamado Raposo Fernandes Associados (RFA) - representaram um forte engajamento de campanha com uso do Facebook ${ }^{7}$. Esse grupo atingiu um alcance tão grande nas redes sociais que supera, em nível de interação no Brasil, a soma dos índices de páginas oficiais de famosos como Madonna, Neymar e Anitta:

Entre o dia 12 de setembro de 2018 e os 30 subsequentes, os endereços alcançaram 12,6 milhóes de interaçóes no Facebook — ou seja, o total de reaçôes a postagens, comentários e compartilhamentos. Mais de 16 milhôes seguem essas páginas. Nos mesmos 30 dias, o jogador Neymar acumulou 1,1 milhão de interaçóes, a cantora Anitta conseguiu 574,8 mil e Madonna, 442,5 mil. Segundo analistas, o sucesso do candidato do PSL nas urnas pode ser explicado, em parte, por essa força na Internet, já

\footnotetext{
7 Segundo a reportagem, "A rede RFA administra, além das páginas de Facebook, sites com nomes parecidos com os da imprensa tradicional: Correio do Poder, Crítica Política, Folha Política, Gazeta Social e Política na Rede. Com isso, conseguem reverter o alto engajamento em cliques e lucrar com anúncios de plataformas. O conteúdo publicado por essas páginas e sites varia entre a republicação de reportagens, mençóes positivas a Bolsonaro e correligionários e divulgação de boatos" (TOLEDO, 2018a).
} 
24 Irineu Francisco Barreto Junior e Gustavo Venturi Junior

que ele não teve apoio de partidos tradicionais ou tempo de TV. (TOLEDO, 2018a).

Figura 4 - Rede pró-Bolsonaro engaja mais do que Madonna e Neymar

\section{Interações}

Rede de páginas teve mais alcance até do que Anitta e Madonna

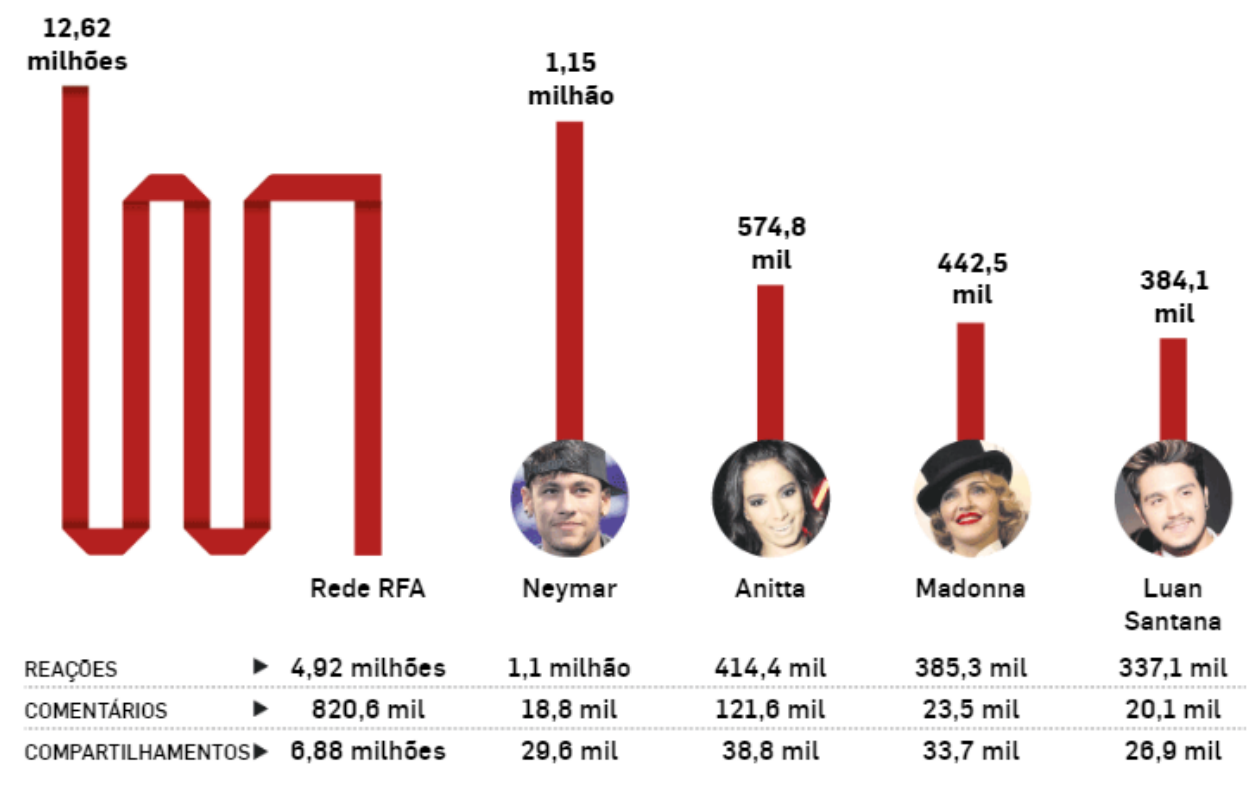

Fonte: Crowdtangle/Avaaz/Estadão Dados apud Toledo (2018a).

A investigação revela que as páginas da RFA surgiram bem antes do pleito de 2018 e tiveram sua ascensão em meio aos protestos de junho de 2013 e da operação Lava Jato, em 2014, vindo a obter consolidação no processo de impeachment de Dilma Rousseff, e posteriormente convergiram no apoio a Bolsonaro.

A empresa que administra o grupo é a Novo Brasil Empreendimentos Digitais Ltda., de propriedade do advogado Ernani Fernandes Barbosa Neto e de Thais Raposo do Amaral Pinto Chaves. As páginas da rede são sempre identificadas com a sigla RFA na descrição. Embora se declare como independente, a rede administra endereços como Apoio a Jair Bolsonaro e, durante a divulgação dos resultados do primeiro turno, comemorou nas páginas vitórias como a dos candidatos Eduardo Bolsonaro e Janaína Paschoal, ambos do PSL. (TOLEDO, 2018a). 
A matéria informa ainda que o maior puxador de interaçôes da RFA é uma página chamada Movimento Contra Corrupção (MCC), atuante ainda no Twitter em defesa do governo Bolsonaro. A entidade foi criada em 2013, no auge dos protestos de rua conhecidos como manifestações de junho, com foco na mobilização virtual e críticas à imprensa.

Figura 5 - Rede pró-Bolsonaro da empresa Raposo Fernandes Associados (RFA)

\section{As páginas de maior alcance no período eleitoral na rede RFA}
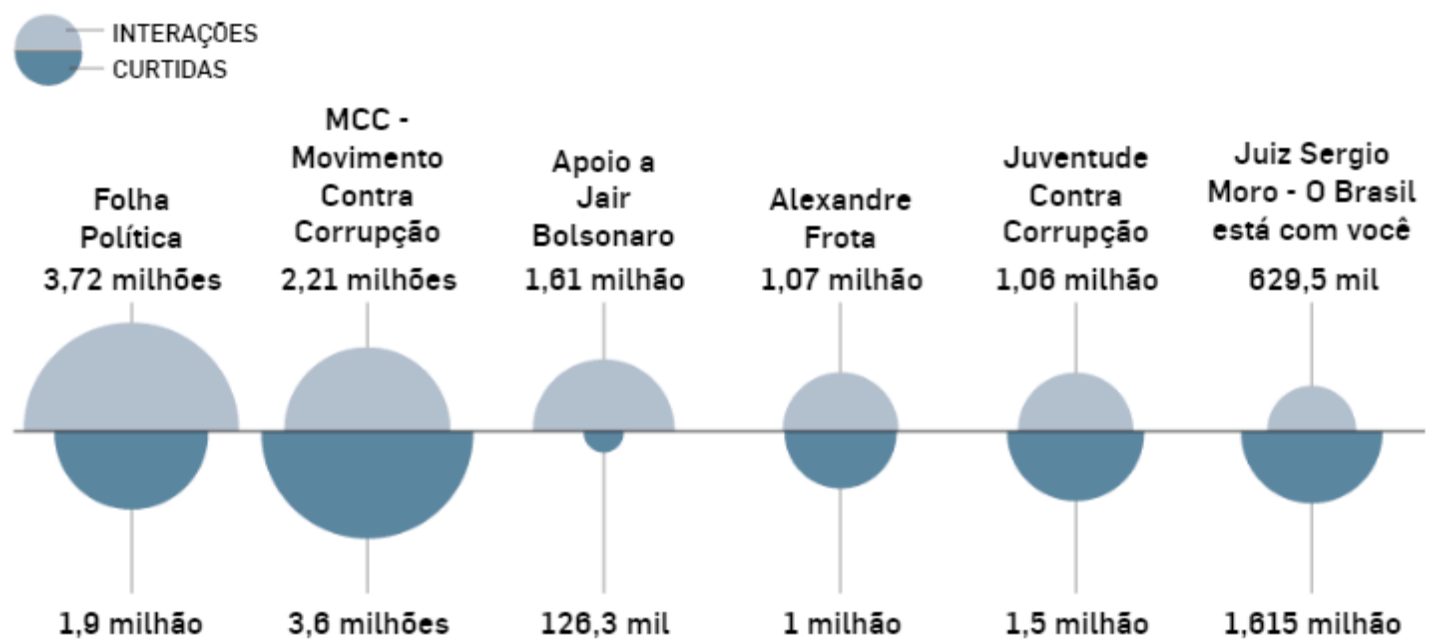

Fonte: Crowdtangle/Avaaz/Estadão Dados apud Toledo (2018a).

Após a denúncia, o Facebook removeu, em 22 de outubro de 2018, um grupo de 68 páginas e 43 contas da rede social controladas pelo grupo Raposo Fernandes Associados (RFA), citado anteriormente (TOLEDO, 2018b). Segundo a empresa, "[...] os donos dessas páginas violaram as políticas de autenticidade e spam ao criar contas falsas e múltiplas contas com os mesmos nomes para administrar essa rede" (TOLEDO, 2018b). O comunicado alega que o conteúdo compartilhado pelas páginas não teve influência sobre a decisão do Facebook, tática comumente utilizada pela plataforma com o intuito de não contrariar preceitos da liberdade de expressão ou acusaçóes de engajamento político liberal, como recebe dos republicanos nos EUA. 
26 | Irineu Francisco Barreto Junior e Gustavo Venturi Junior

\section{Análise de pesquisas de intenção de voto na eleição presidencial 2018}

Conforme assinalado anteriormente, é bastante difícil apontar uma evidência única que possa explicar processos eleitorais complexos como a eleição presidencial brasileira de 2018, uma vez que fenômenos dessa monta são bastante multifacetados e devem ser analisados por diferentes perspectivas. Ainda mais desafiador é demonstrar de forma inequívoca a probabilidade de correlação entre a estratégia de disseminação de fake news e os resultados do pleito. Porém, é bastante plausível estabelecer hipóteses de que essa influência tenha ocorrido, dada a sofisticada estratégia comunicacional adotada na campanha eleitoral vencedora, apresentada ao longo deste artigo, além do demonstrado potencial de influência tóxica que pode ser exercido pelas fake news.

$\mathrm{O}$ artigo apresenta, a seguir, dados das pesquisas eleitorais divulgados pelos institutos de pesquisa Datafolha e Ibope ao longo da eleição de 2018, com foco nas taxas de intenção de voto e rejeição, números associados aos então candidatos e historicamente influenciáveis em decorrência das estratégias de campanha. O então candidato Bolsonaro liderou as pesquisas de intenção de voto ao longo de todas as tomadas divulgadas a partir de setembro, depois da Justiça Eleitoral indeferir o registro da candidatura do ex-presidente Lula ${ }^{8}$ e seu nome ser substituído pelo antigo prefeito da capital paulista, Fernando Haddad.

A liderança de Bolsonaro perdurou mesmo após o atentado contra ele perpetrado, em 6 de setembro de 2018, que forçou o candidato a interromper sua campanha e se abster de conceder entrevistas e participar de debates eleitorais. Além deste grave episódio, o antigo capitão do exército enfrentava a limitação de possuir o menor tempo de campanha eleitoral gratuita de rádio e televisão entre os candidatos mais competitivos, o que evidencia a importância de sua estratégia nas redes sociais e pelo WhatsApp.

\footnotetext{
${ }^{8} \mathrm{O}$ registro da candidatura foi indeferido pelo Tribunal Superior Eleitoral em 01 de setembro de 2018. (BRASIL, 2018).
} 
Gráfico 1 - Pesquisas Eleitorais 2018: Primeiro Turno

Datafolha: Intenção de voto para presidente da República

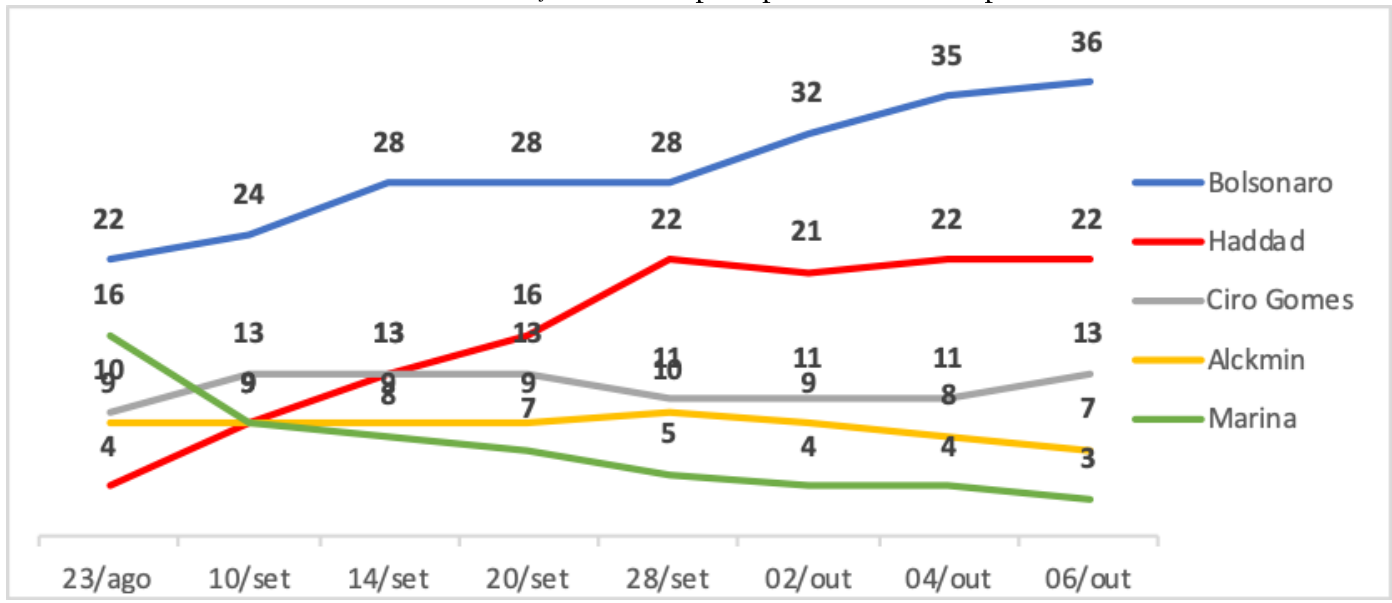

Fonte: Pesquisa Datafolha... (2018a).

Gráfico 2 - Pesquisas Eleitorais 2018: Primeiro Turno

Ibope: Intenção de voto para presidente da República

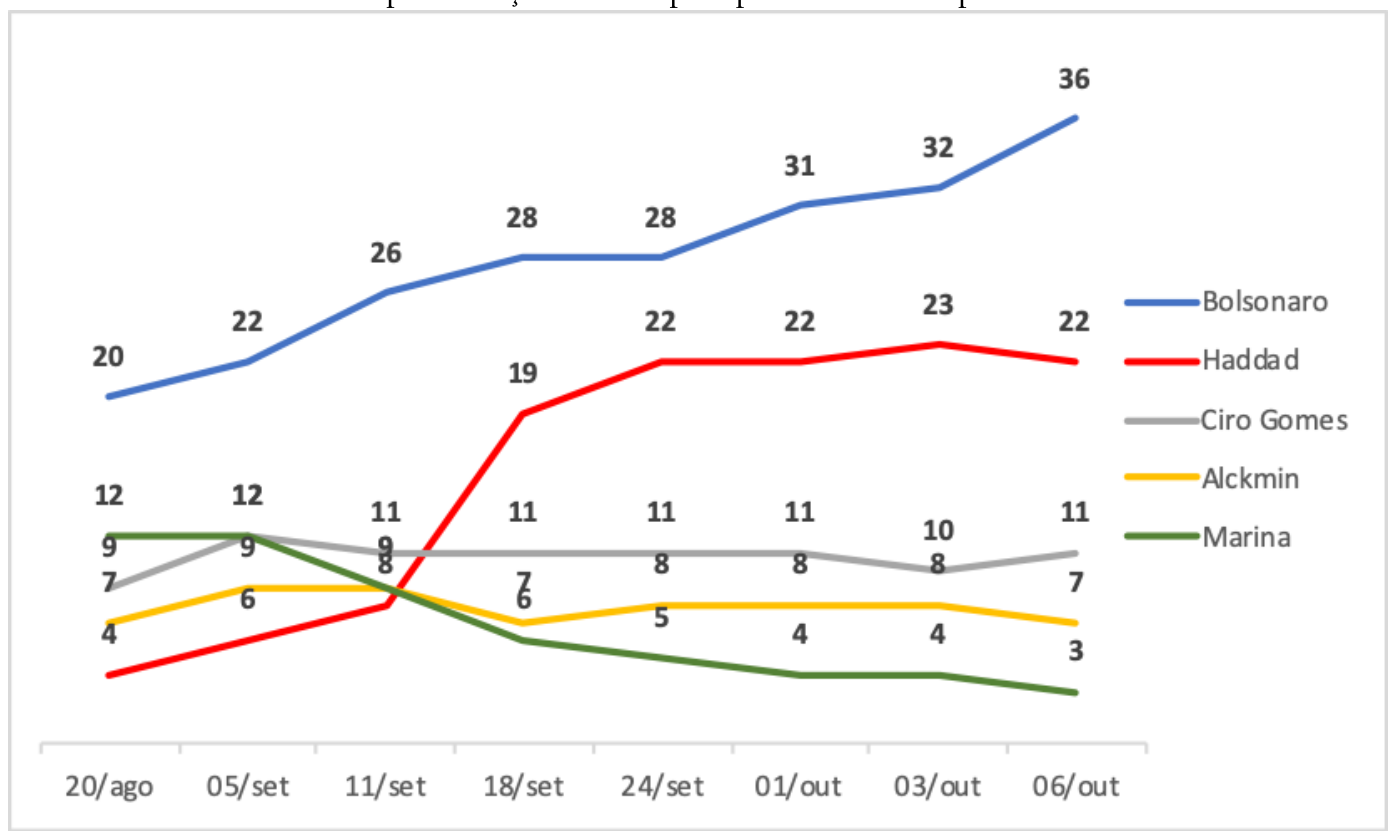

Fonte: Intenção... (2018). 
Os Gráficos 1 e 2 retratam a liderança inconteste da candidatura Bolsonaro nas pesquisas de intenção de voto Datafolha e Ibope, mesmo após o atentado perpetrado no início de setembro. O escasso tempo de inserções de rádio e TV, somado ao afastamento do candidato por força das cirurgias reparatórias dos ferimentos sofridos, reforçam a hipótese de associação entre essa liderança e o êxito das estratégias de comunicação nas redes sociais e grupos de WhatsApp.

Quanto à taxa de rejeição, havia no meio político uma percepção difusa de que Bolsonaro seria um candidato facilmente derrotável no segundo turno do pleito presidencial (DATAFOLHA..., 2018), em decorrência da ampla rejeição ao seu nome amealhara durante sua atuação como parlamentar. Os números do Datafolha e Ibope sustentam essa evidência e as taxas de rejeição ao nome de Bolsonaro foram as mais elevadas ao longo do período escrutinado pelos institutos.

Porém o comportamento mais atípico, demonstrado nos Gráficos 3 e 4, é o acentuado ritmo de incremento das taxas de rejeiçáo do candidato Haddad. No período entre o final de agosto de 2018 até o final de setembro, às vésperas do primeiro turno, a rejeição ao nome de Haddad saltou do patamar próximo de $20 \%$ para em torno dos $40 \%$, praticamente o dobro. É bastante plausível a hipótese de que os disparos em massa de campanha e as fake news tenham potencializado os efeitos da taxa de rejeição ao candidato Haddad, pois estes ocorreram concomitantemente à disparada dessa taxa de detratores, como apuraram Ibope e Datafolha.

As análises agregadas dos números de intenção de voto e rejeição ao nome de Fernando Haddad coadunam com essa perspectiva exploratória, mesmo com a necessária ressalva de que não é possível realizar uma associação determinística entre os fenômenos. Não obstante as limitações de correlação, os dados das pesquisas eleitorais mostram que, após o indeferimento da candidatura do ex-presidente Lula, a intenção de voto de Haddad quintuplicou, e que a curva de intenção de voto ascendente foi interrompida de forma concomitante com a estratégia de disparo em massa de mensagens em prol da candidatura Bolsonaro, uma ação articulada de influenciadores digitais e disseminação ininterrupta de fake news, conforme demonstrado anteriormente no artigo. 
Gráfico 3 - Pesquisas Eleitorais 2018: Primeiro Turno

Datafolha: Taxa de Rejeição dos candidatos: Presidente da República

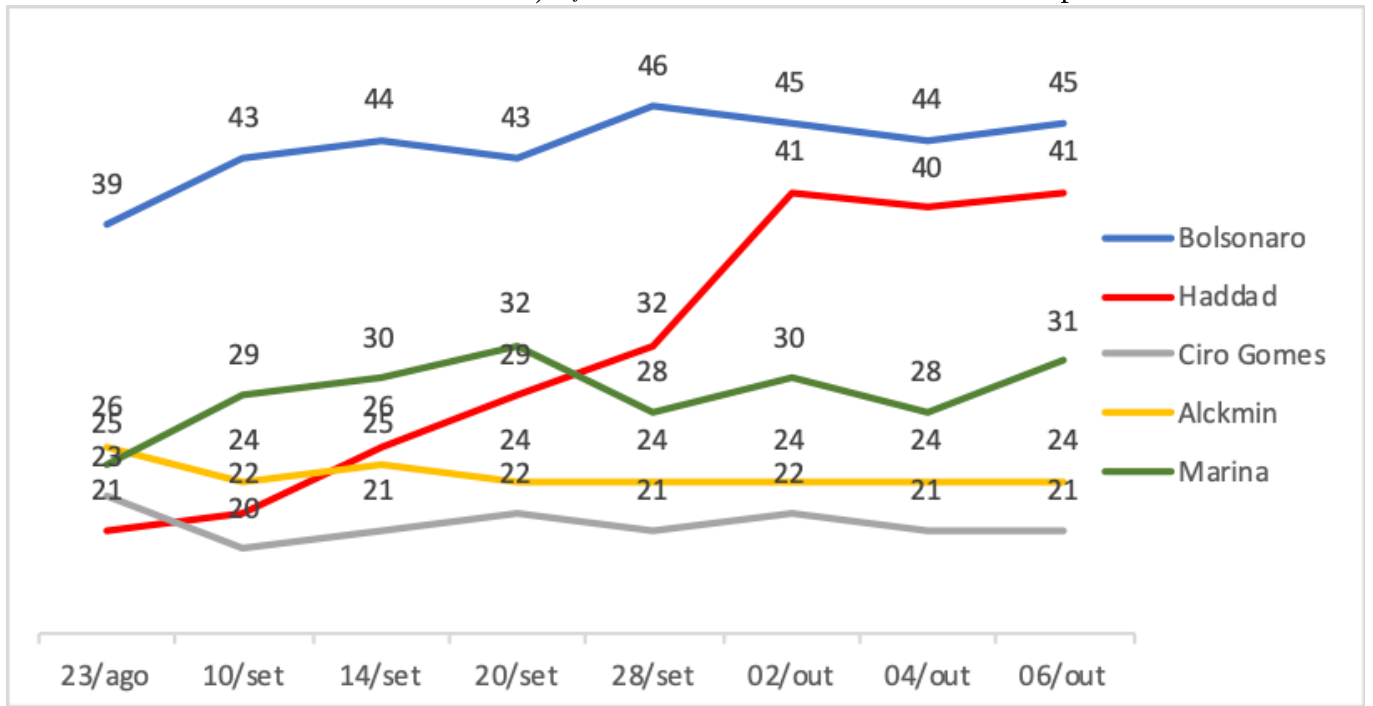

Fonte: Pesquisa Datafolha... (2018b).

Gráfico 4 - Pesquisas Eleitorais 2018: Primeiro Turno IBOPE: Taxa de Rejeição dos candidatos: Presidente da República

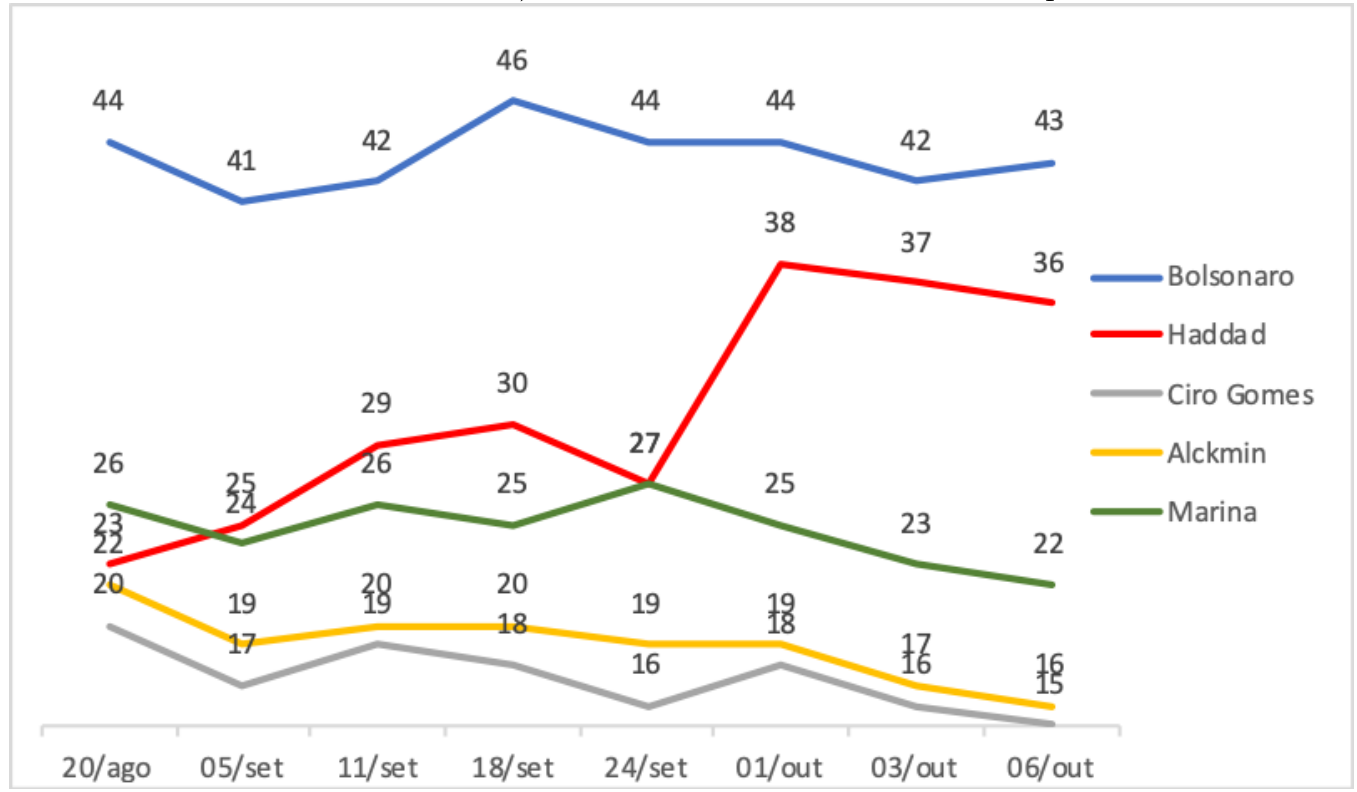

Fonte: Rejeição... (2018). 
Assim, mesmo considerando que não é sustentável uma correlação estatística entre os efeitos da disseminaçáo das fake news e a intenção de voto do eleitorado expressa nas pesquisas Ibope e Datafolha, os dados sugerem que houve sincronicidade e correlação temporal entre a disparada da taxa de rejeição ao então candidato Fernando Haddad e a estratégia de propagação das fake news.

Reitera-se que as fake news requerem ambientes políticos tóxicos, polarizados, nos quais os elementos oferecidos aos eleitores para a tomada de decisóes racionais se escasseiam, com o recrudescimento de distorções, mensagens deliberadamente enviesadas ou difamatórias. Esse foi o ambiente de tempestade perfeita que culminou em um meio propício para a propagação das fake news. D’Ancona (2018, p. 57) também aborda essa ausência de racionalidade nas decisões impulsionadas por fake news. O autor aponta que essa é a principal característica que define o mundo da pósverdade, que mitiga a importância da busca da realidade por meio de um processo de avaliação racional e conclusivo. "Você escolhe sua própria realidade como se escolhesse comida de um bufê. Também seleciona sua própria mentira, de modo não menos arbitrário" (D’ANCONA, 2018, p. 57). Ele afirma ainda que "[...] por mais tentador que seja não levar a sério as notícias falsas, elas possuem consumidores entusiásticos no próprio ápice do poder" (D’ANCONA, 2018, p. 57). Tudo o que importa é que elas pareçam verdadeiras e repercutam.

\section{Fake news em imagens}

Conforme anunciado na introdução, a pesquisa que ampara este artigo compilou em torno de 160 imagens relacionada à campanha eleitoral que circularam, entre setembro e novembro de 2018, em grupos de WhatsApp e que podem ser associadas à estratégia de propagação das fake news. Essa associação entre as imagens e o fenômeno das fake news é devida aos indícios de distorção da realidade que carregam em sua carga imagética, ao mesmo tempo em que seu teor dialoga com a realidade adjacente ao ano de 2018.

As imagens foram selecionadas com base em critérios que as enquadrem quanto à sua relevância, concatenação com aspectos mais gerais da política brasileira e elementos culturais e comportamentais que possam atribuir uma aura de credibilidade e potencializar seus efeitos. Os teores retratados estabelecem diálogo com as unidades anteriores desse artigo e simbolizam as características mais destacadas das fake news. Não são apenas falsas, mas deliberadamente falsas, conectadas a um contexto e componentes de estratégia comunicacional voltada a interesses econômicos ou políticos, no caso em análise a segunda alternativa. 
$\mathrm{O}$ artigo disponibiliza online $\mathrm{e}^{9}$ as imagens mais relevantes que possibilitam o estabelecimento de nexos entre a campanha eleitoral e o contexto político brasileiro mais amplo, assim como que sejam associadas a temas eleitos prioritários na agenda do então candidato Bolsonaro: ameaça de avanço comunista sobre o Brasil, denúncia de deterioração dos costumes deliberadamente associada ao feminismo e à pauta LGBT, riscos ao "modelo tradicional de família brasileira", combate a uma suposta doutrinação ideológica nas escolas e resgate de valores religiosos.

\section{Considerações finais}

Conforme apontado na introdução, o objetivo principal deste artigo foi analisar a disseminação das fake news durante a campanha presidencial de $2018 \mathrm{e}$ apontar possíveis efeitos dessa prática nos resultados do pleito. Após as evidências apresentadas e nexos estabelecidos ao longo do artigo, é possível analisar algumas hipóteses. Primeiro, a intencionalidade da disseminação das fake news foi evidenciada pelo impulso artificial que receberam nas redes sociais, movimento que leva os algoritmos dessas plataformas a aumentarem a exposição orgânica dos conteúdos e, principalmente, pelo impulsionamento pago ou articulado em grupos de WhatsApp.

O Brasil se tornou o primeiro grande case mundial de eleiçóes nas quais houve o uso do WhatsApp para propagaçáo de fake news, considerando que a saída do Reino Unido da zona do Euro (Brexit) e as eleições de Trump, nos EUA, levantaram evidências de uso de ferramentas comunicacionais diversas principalmente o impulsionamento de conteúdo direcionado a perfis formulados a partir de dados pessoais indevidamente subtraídos de redes sociais, especialmente o Facebook, eventos que ficaram marcados pela ação da empresa denominada Cambridge Analytica. No Brasil, o uso do WhatsApp mitigou a necessidade de direcionamento das mensagens para perfis previamente formulados, como se viu ao longo do artigo.

Quanto ao necessário aggiornamento entre as fake news e o cenário cultural, comportamental e político mais amplo, a pesquisa mostrou que as notícias falsas prosperaram num ambiente de debate político marcadamente tóxico, fator que provoca a erosão da qualidade da decisão eleitoral por afastá-la da desejável escolha racional entre diferentes candidatos ou plataformas eleitorais. Essa estratégia conduz, comumente, os eleitores ao sufrágio com bases emocionais, que podem ser o medo ou

9 Conforme já indicado, as imagens foram abrigadas online, sob responsabilidade dos autores do artigo, e estão disponíveis em: <https://www.portalsid.com/fake-news-em-imagens>. 
o ódio, e eleitores nutridos desses sentimentos não costumam fazer boas escolhas, racionais ou pragmáticas, movidas por seus interesses reais.

Conforme assinalado anteriormente no artigo, não é possível correlacionar estatisticamente os efeitos da disseminação das fake news e a intenção de voto do eleitorado expressa nas pesquisas Ibope e Datafolha. Cenários das disputas eleitorais recebem efeitos de diversos fatores - tais como a propaganda eleitoral obrigatória de rádio e televisão, campanhas de rua e debates entre candidatos - e essa gama de eventos influencia a tomada de decisão dos eleitores. Não obstante, o contexto da eleição presidencial de 2018 sugere que houve sincronicidade temporal entre a disparada da taxa de rejeição ao então candidato Haddad e a estratégia de propagação das fake news.

Atualmente, as ações na Justiça Eleitoral pouco prosperaram na apuração das responsabilidades quanto ao financiamento privado do impulsionamento de conteúdo, que é vedado pela legislação eleitoral, ou vantagens indevidas auferidas por candidaturas, propiciadas pela explosão das fake news, causando a impressão de que nada de extraordinário tenha ocorrido no pleito de 2018. Os canais de disseminação de conteúdo falso, distorcido, enviesado politicamente, fraudulento ou calunioso continuam ativos e em pleno funcionamento ao longo de 2019, servindo como estratégia complementar de comunicação política para governos, parlamentares e aspirantes a candidaturas futuras. WhatsApp e Twitter mantêm o clima de conflagração presenciado no pleito e servem para manter seguidores políticos mobilizados, engajados, investindo na fidelidade das bases de sustentação e potencialmente angariando eleitores para sufrágios futuros. Nada indica que haverá arrefecimento das fake news no horizonte político próximo.

Irineu Francisco Barreto Junior é Pós-Doutor em Sociologia pela Universidade de São Paulo (USP). Doutor em Ciências Sociais pela Pontifícia Universidade Católica de São Paulo. Professor do Programa de Mestrado em Direito da Sociedade da Informação e do Curso de Graduação em Direito da FMU-SP. Coordenador do Grupo de Pesquisa Direito, Tecnologia e Sociedade. Analista de Pesquisas da Fundação Sistema Estadual de Análise de Dados Seade. E-mail neubarreto@hotmail.com

Gustavo Venturi Junior é Doutor em Ciência Política pela USP.
Professor do Programa de Pós-Graduação e do Departamento de 


\section{Sociologia da Faculdade de Filosofia, Letras e Ciências Humanas (FFLCH) da USP. Coordenou o Núcleo de Opinião Pública da Fundação Perseu Abramo (2007-2014), desenvolvendo pesquisas de cultura politica e estudos sobre marcadores sociais da diferença. E-mail:gventuri@usp.br.}

\section{Referências}

BARRETO JUNIOR, Irineu Francisco; VENTURI JUNIOR, Gustavo. Dados pessoais na Internet: análise do seu status enquanto mercadoria na sociedade da informação. Anais do $41^{\circ}$ Encontro Anual da ANPOCS, 2017, Caxambú, MG. Disponível em: <http://www.anpocs.com/ index.php/papers-40-encontro-2/gt-30/gt02-25/10599-dados-pessoais-na-Internet-analise-do-seustatus-enquanto-mercadoria-na-sociedade-da-informacao/file. Acesso em: 10 nov. 2017>.

BENITES, Afonso. A máquina de Fake News nos grupos a favor de Bolsonaro no WhatsApp. El País, 28 set. 2018. Disponível em: <https://brasil.elpais.com/brasil/2018/09/26/politica/1537997311 _859341.html>. Acesso em: 18 maio 2019.

BRASIL. Tribunal Superior Eleitoral. TSE indefere pedido de registro de candidatura de Lula à Presidência da República. [Portal do TSE], 01 set. 2018. Disponível em: <http://www.tse.jus.br/ imprensa/noticias-tse/2018/Setembro/tse-indefere-pedido-de-registro-de-candidatura-de-lula-apresidencia-da-republica>. Acesso em 01. set. 2019

CASTRO, Leandro Nunes de. Computação e Desinformação: tecnologias de desinformação online. In: RAIS, Diogo (Coord.). Fake News: a conexão entre desinformação e o Direito. São Paulo: Thomson Reuters Brasil, 2018.

D’ANCONA, Matthew. Pós Verdade: a nova guerra contra os fatos em tempos de Fake News. Barueri: Faro Editorial, 2018.

DATAFOLHA: Bolsonaro perde todos os cenários de $2^{\circ}$ turno; Ciro vence Haddad. Uol, 28 set. 2018. Disponível em: <https://noticias.uol.com.br/politica/eleicoes/2018/noticias/2018/09/28/ datafolha-bolsonaro-perde-todos-os-cenarios-de-2-turno-ciro-vence-haddad.htm>. Aceso em: 03 jan. 2020

ELY, Débora. A máquina de campanha de Bolsonaro pelo WhatsApp. Gaúcha ZH, 15 out. 2018. Disponível em: <https://gauchazh.clicrbs.com.br/politica/eleicoes/noticia/2018/10/a-maquina-decampanha-de-bolsonaro-pelo-whatsapp-cjnb0prtp05df01 rxdx7k9mqc.html>. Acesso em: 25 out. 2018.

GRAGNANI, Juliana. Como identificar os diferentes tipos de fakes e robôs que atuam nas redes. BBC News, 16 dez. 2017. Disponível em: <https://www.bbc.com/portuguese/brasil-42172154>. Acesso em: 09 mai. 2019. 
GROSS, Clarissa Piterman. Fake News e Democracia: discutindo o status normativo do falso e a liberdade de expressão. In: RAIS, Diogo (Coord.). Fake News: a conexão entre desinformação e o Direito. São Paulo: Thomson Reuters Brasil, 2018.

INTENÇÃO de voto no $1^{\text {o }}$ turno para presidente. Uol, 6 out. 2018. Disponível em: $<$ https://noticias.uol.com.br/politica/eleicoes/2018/pesquisas-eleitorais/brasil/1-turno/>. Acesso em: 09 fev. 2020.

JAIR BOLSONARO leva facada durante ato de campanha em Juiz de Fora. G1, 06 set. 2018. Disponível em: <https://g1.globo.com/mg/zona-da-mata/noticia/2018/09/06/ato-de-campanha-debolsonaro-em-juiz-de-fora-e-interrompido-apos-tumulto.ghtml>. Acesso em: 19 fev. 2020.

MACHADO, Caio; KONOPACKI, Marco. Poder Computacional: Automação no uso do WhatsApp nas Eleições. 2019. Disponível em: <https://itsrio.org/pt/publicacoes/automacao-eleicoes/>. Acesso em: 16 maio 2019.

MELLO, Patrícia Campos. Empresários bancam campanha contra o PT pelo WhatsApp. Jornal Folha de S. Paulo, 18 out. 2018. Disponível em: <https://wwwl.folha.uol.com.br/poder/2018/10/ empresarios-bancam-campanha-contra-o-pt-pelo-whatsapp.shtml>. Acesso em: 20 fev. 2020.

MELLO, Patrícia Campos; RODRIGUES, Artur. Fraude com CPF viabilizou disparo de mensagens de WhatsApp na eleição: documentos na Justiça do Trabalho e relato de ex-funcionário da empresa Yacows mostram irregularidade em serviço na campanha. Folha de S. Paulo, 02 dez. 2018. Disponível em: <https://www1.folha.uol.com.br/poder/2018/12/fraude-com-cpf-viabilizou-disparode-mensagens-de-whatsapp-na-eleicao.shtml>. Acesso em: 20 fev. 2020.

PASQUINI, Patrícia. "Apoio voluntário é algo que o PT desconhece", diz Bolsonaro. Folha de $S$. Paulo, 18 out. 2018. Disponível em: <https://www1.folha.uol.com.br/poder/2018/10/apoiovoluntario-e-algo-que-o-pt-desconhece-diz-bolsonaro-apos-reportagem-sobre-financiamento-decampanha-contra-o-pt.shtml>. Acesso em: 17 mar. 2020.

PESQUISA DATAFOLHA 2018. Confira os resultados das pesquisas para presidente, governador e senador. Folha de S. Paulo, 27 out. 2018a. Disponível em: <https://arte.folha.uol.com.br/ poder/eleicoes-2018/pesquisa-datafolha/\#/presidente/segundo/brasil/ intencao-de-voto-estimuladavotos-validos/total/total/total>. Acesso em: 02 set. 2019.

PESQUISA DATAFOLHA 2018. Confira os resultados das pesquisas para presidente, governador e senador. Folha de S. Paulo, 30 ago. 2018b. Disponível em: <https://arte.folha.uol.com.br/ poder/eleicoes-2018/pesquisa-datafolha/\#/presidente/primeiro/brasil-com-

haddad/rejeicao/total/total/total>. Acesso em: 02 set. 2019.

RAIS, Diogo. Fake News e Eleições. In: RAIS, Diogo (Coord.). Fake News: a conexão entre desinformação e o Direito. São Paulo: Thomson Reuters Brasil, 2018.

RAIS, Diogo; HENNEMANN, Gustavo. Fake News: do que se alimentam, como se reproduzem? Mackenzie, 08 maio 2018. Disponível em: <https://www.mackenzie.br/fakenews/noticias/arquivo/ $\mathrm{n} / \mathrm{a} / \mathrm{i} /$ fake-news-do-que-se-alimentam-como-se-reproduzem/?utm_campaign=Mackenzie $>$. Acesso em: 05 fev. 2020.

REJEIÇÃO dos candidatos. Uol, 06 out. 2018. Disponível em: <https://noticias.uol.com.br /politica/eleicoes/2018/pesquisas-eleitorais/brasil/rejeicao/>. Acesso em: 02 set. 2019.

TOLEDO, Luiz Fernando. Rede pró-Bolsonaro engaja mais do que Madonna e Neymar. Estadão, 12 out. 2018a. Disponível em: <https://politica.estadao.com.br/noticias/eleicoes,rede-pro-bolsonaroengaja-mais-do-que-madonna-e-neymar,70002544629>. Acesso em: 20 fev. 2020. 
TOLEDO, Luiz Fernando. Maior rede de mentiras pró-Bolsonaro do Facebook é excluída após denúncia do 'Estado'. Jornalistas Livres, 22 out. 2018b. Disponível em: $<$ https://jornalistaslivres.org/maior-rede-de-mentiras-pro-bolsonaro-do-facebook-e-excluida-aposdenuncia-do-estado/>. Acesso em: 19 fev. 2020.

Texto recebido em 04 de setembro de 2019. Aprovado em 05 de fevereiro de 2020. 